\title{
Biological Control of Rice Sheath Blight Disease (Rhizoctonia solani) Using Bio-pesticides and Bio-control Agents
}

\author{
M M Rashid ${ }^{1 *}$, M R Bhuiyan², H A Dilzahan², M A Hamid³, N Hasan³, M A I Khan², M A Latif ${ }^{2}$
}

\begin{abstract}
A series of experiments were conducted in Plant Pathology Laboratory at Bangladesh Rice Research Institute (BRRI), Gazipur to know the efficacy of four bio-pesticides Recharge, Microtech1, Agroplus and Chitin and two bio-control agents (Trichoderma harzianum and Bacillus subtilis) on the major rice disease sheath blight (ShB) caused by Rhizoctonia solani in in-vitro and field condition. One fungicide Nativo (Tebuconazole 50\% + Trifloxystrobin 25\%) and one disease control (without any treatments) were also included as treatment for comparison. Radial mycelia growth of $R$. solani was mostly inhibited by a Bangladesh Trichoderma harzianum (BT1), Recharge and chemical fungicide Nativo 75 G at 48 hours of dual contact of $R$. solani and tested bio-pesticides or bio-control agents in in-vitro. The other bio-pesticides along with B. subtilis didn't show any inhibition effect on the mycelia growth of R. solani which was similar to control (only water) treatment. Fungal inhibition $87.5 \%$ and $86.3 \%$ of Rhizoctonia solani was obtained by Recharge and Trichoderma harzianum (BT1), respectively which was nearly similar to the chemical treatment Nativo $(96.3 \%)$ in in-vitro dual culture method compared to control treatment. In net house condition, $74 \%$ sheath blight disease was inhibited by soil application of Recharge $\left(0.3 \mathrm{~g} / \mathrm{m}^{2}\right.$ with $50 \mathrm{ml}$ water) for two times at the time of transplanting and 30 days after transplanting (DAT), whereas similar soil application of B. subtilis $\left(\mathrm{OD}_{600}=0.3\right)$ was not found effective to control the ShB disease ( $<30 \%$ disease reduction). The highest $\mathrm{ShB}$ disease was reduced by the chemical control Nativo 75 G $(94.2 \%)$ followed by BT1 $(89 \%)$, bio-pesticide Recharge $(70.8 \%)$, Microtech1 (37.4\%) and Chitin (61.3\%) compared with the disease control when the tested materials were sprayed for two times ( 3 days before and 4 days after inoculation).
\end{abstract}

Key words: Efficacy, bio-pesticide, fungal inhibition, Rhizoctonia solani.

\section{INTRODUCTION}

Bio-pesticides offer powerful tools to create a new generation of sustainable agriculture products. They are the most likely alternatives to some of the most problematic chemical pesticides currently in use. Bio-pesticides offer solutions to concerns such as pest resistance, traditional chemical pesticides and public concern about side effects of pesticides on the surrounding environment and ultimately on human health. Bio-pesticides are the rich combination of beneficial microorganisms which are vital to soil health as well as pathogen inhibition (Mishra et al., 2015; Sindhu et al., 2016; Islam et al., 2019; Naeimi et al., 2019; Raj et al., 2019).

There are several constraints of rice production and its low yield in Bangladesh. A total of 79 diseases of rice was recorded worldwide $(\mathrm{Ou}, 1985)$ and 20 rice diseases was found in Bangladesh and sheath blight was found one of the major diseases of rice (Mian et al. 1983). Among the major rice diseases sheath blight (ShB) caused by the fungal pathogen Rhizoctonia solani (R. solani) is one of the most economically important diseases in Bangladesh and the world. It is a global rice production constraint incurring economic loss to an extent of $4 \%$ annually (Zhong et al., 2007). Sheath blight is becoming as an increasing problem for rice cultivation in Bangladesh for all the three seasons Aus, Aman and Boro (Miah et al., 1985; BRRI, 2018). Sheath blight of rice takes place in all rice growing areas of the world (Ou, 1985; Savary et al., 2006) and may cause up to a $50 \%$ decrease in the rice yield under favourable conditions around the world

1Plant Pathology Division, Bangladesh Rice Research Institute, Regional Station, Cumilla, Bangladesh. 2Plant Pathology Division, Bangladesh Rice Research Institute, Gazipur, Bangladesh. ${ }^{3}$ Russell IPM Ltd, 45 First Avenue, Deeside Industrial park, Deeside, Flintshire, CH52NU, UK. *Corresponding author's E-mail: mamunbrri@gmail.com 
(Zheng et al., 2013). Sheath blight caused 14$17 \%$ yield loss in different varieties during Aus, Aman and Boro seasons in Bangladesh (Shahjahan et al., 1986). High temperature and relative humidity during crop growth favor development of sheath blight disease, high tillering, short stature and high nitrogen responsive varieties are comparatively more susceptible as the micro climates inside the rice canopy is more favorable than those of the traditional ones of tall plant type with low tillering ability (Miah et al., 1985). Application of fungicides is the major measure for controlling sheath blight of rice for over three decades in Asian countries (Zheng et al., 2013).

Fungal bio-pesticides can be used to control insects, bacteria, nematodes, fungi and weeds (Manoharachary et al., 2014). Mechanism of bio-control varies and depends on both the pesticidal fungus and the target pest. Trichoderma secretes enzymes such as chitinolytic enzymes, glucanases, cellulases, and proteases that help in the biological control of plant diseases (Mishra et al., 2015). However, extensive and continuous use of a single chemical may lead to undesirable effects such as residual toxicity and environmental pollution, and also increases the risk of resistance development (Brent and Hollomon, 1998). Therefore, it is necessary to develop environmentally friendly, low residual and effective alternative methods for the management of sheath blight (ShB) disease.

Cultural practices, chemical and biological control, disease forecasting, host genetic resistance, typically major gene resistance are commonly used for controlling ShB. But cultural practices are not found effective in all locations and its efficacy mainly depends on disease incidence records. Agrochemicals and their behaviour of natural degradation harm the environment, causing major ecological and health problems. An ecofriendly and sustainable crop production in agriculture is possible by using bio-pesticides, a formulated product using bio-control agents. The use of biological agents has not widely popular for controlling ShB even though biological control is an environmentally friendly and cost-effective substitute to chemical. Now-a-days, the use of antagonistic bacteria as biological control is considered as the best alternative way to reduce the application of chemicals in field (Yang et al., 2007; Misk and Franco, 2011; Raj et al., 2019).

The extensive use of synthetic organic chemicals in the past decades has led to a number of long-term environmental problems (Arora et al., 2012). Chemical fertilizers and pesticides are continuously accumulating in the environment, harming the ecosystem, causing pollution, and inflicting diseases at alarming levels (Gerhardson, 2002; Arora et al., 2010). The heavy use of pesticides has already caused grave damage to health, ecosystems, and groundwater. Therefore, this study was undertaken to know the efficacy of environment friendly bio-pesticides along with bio-control agents against one of the major rice disease sheath blight.

\section{MATERIALS AND METHODS}

The experiments were conducted at Plant Pathology Division, Bangladesh Rice Research Institute (BRRI) during 2016-17. Three biopesticides namely Recharge (Russel IPM, UK), Microtech (B. subtilis) and Chitin; two biocontrol agents Trichoderma harzianum (BT1) and Bacillus subtilis; one chemical Nativo were tested in the experiments.

Recharge is a rich combination of beneficial soil microorganisms (Glomus spp, Bacillus spp. Trichoderma spp.) which are vital to soil health. The application of Recharge vitalizes the soil and restores its ability to function properly by providing vital background protection to the crop from invasive pests and diseases. Recharge only puts back what the soil has already lost due to excessive pesticide applications. Recharge is a 
new product came from Russel IPM, UK for field evaluation in Bangladesh. The other three bio-pesticides Microtech1 (Bacillus subtilis), Agroplus and Chitin were supplied by different pesticide companies of Bangladesh.

Two bio-control agents Trichoderma harzianum (BT1) isolated from rhizosphere of rice plant and Bacillus subtilis was derived from Datura metel seed extract (Wang et al., 2018). A commonly used effective fungicide Nativo 75 G (Tebuconazole +Trifloxystrobin) of Bayer Crop Science was used as standard chemical control treatment to compare the efficacy of bio-pesticides or the bio-control agents following the method of Groth (2005).

Isolation of $\boldsymbol{R}$. solani. The test pathoges $R$. solani was isolated from the infected sheath. Infected sheath samples were cut off with a pair of sterilized scissors, kept in a sterilized polyethylene bag and brought into the laboratory for microscopic study and isolation work. The fungus was isolated from infected parts of the rice plants following tissue planting method (Bashar et al., 2010). Sheath blight infected sheath with culm was cut into small pieces $(5-6 \mathrm{~mm})$ with the help of sterilized scissors. The cut pieces were washed with sterile water for two minutes and then surface sterilized by 5\% Clorox for 2-3 minutes. Finally, these pieces of sheath were washed with sterile water for 2-3 minutes and were dried on sterile tissue paper. The dried samples were placed on potato dextrose agar (PDA) plate and incubated for seven days at room temperature $(25 \pm 2 \circ \mathrm{C})$. The isolate was purified by the hyphal tip method which consists of cutting the hyphal tip of a growing mycelium. Fungus was identified based on mycelial growth, colony character, sclerotia formation and sclerotial size. The fungal strain was stored on PDA medium at $4^{\circ} \mathrm{C}$.

The experiments were conducted both in in vitro and also in net house conditions to confirm the efficacy of the treatments.
In-vitro experiment. In-vitro experiment was conducted in the Plant Pathology Laboratory, BRRI, Gazipur. The treatments were T1: Trichoderma harzianum (BT1) @ OD600=1, T2: Microtech1 containing Bacillus. subtilis @ 20 $\mu \mathrm{l} / \mathrm{ml}, \mathrm{T3}$ : B. subtilis @ OD600=1, T4: Agroplus @ $20 \mu \mathrm{l} / \mathrm{ml}$, T5: Recharge (Glomus spp, Bacillus spp. and Trichoderma spp.) @ $20 \mathrm{mg} / \mathrm{ml}$, T6: Chitin@ $20 \mu \mathrm{l} / \mathrm{ml}$, T7: Nativo 75 G @ 20 $\mathrm{mg} / \mathrm{ml}$ as a chemical control and T8: Control (only water). The in vitro antagonistic assay was performed according to the dual culture method (Wang et al., 2018) on PDA medium. Bio-pesticides and chemical @ 0.3\% (w/v or $\mathrm{v} / \mathrm{v})$ were over lapped $(50 \mu \mathrm{l})$ on the PDA plates. Then six mm mycelial block of $R$. solani isolated from pure culture was disposed at the center of Petri dishes and incubated at $25 \pm 2{ }^{\circ} \mathrm{C}$ for 2-3 days. The antagonistic activity of the bio-pesticides was estimated by the inhibition of the fungal growth in comparison to a solely cultivated fungal agar disk. The fungal growth was monitored by measuring the diameter in centimeter of the colony. Each treatment was tested in three different plates and the experiment was carried out twice. Effect of bio-pesticides, bio-control agents and chemical on the growth inhibition of $R$. solani over control treatment was calculated as percent inhibition using the following formula reported by Satish et al., 2007 and Dubey et al., 2009.

Fungal growth inhibition $\%=(\mathrm{C}$ $\mathrm{T} / \mathrm{C}) \times 100$, Where $\mathrm{C}=R$. solani growth in the control treatment, $T=R$. solani growth in the bio-pesticide or bio-control agent or chemical treatments.

Net house experiments. These experiments were conducted to know the efficacy of some bio-pesticides and bio-control agents on sheath blight (ShB) disease of rice in net house condition using soil application, root dipping and spray methods. Two seedlings of test variety BR11 were transplanted maintaining three hills per pot. Three methods 
namely soil application, root dipping and spray were used for treatments application. In soil application and root dipping method, the treatments were $T_{1}=$ Recharge $\left(0.3 \mathrm{~g} / \mathrm{m}^{2}\right.$ with $50 \mathrm{ml}$ water) by soil application at two times; 0 days after transplanting (DAT), $30 \mathrm{DAT}, \mathrm{T}_{2}=$ Root dipping with Recharge $\left(0.3 \mathrm{~g} / \mathrm{m}^{2}\right.$ with 50 $\mathrm{ml}$ water) of seedlings for $30 \mathrm{~min}, \mathrm{~T}_{3}=\mathrm{T}_{1}+\mathrm{T}_{2}$, $\mathrm{T}_{4}=$ Bacillus subtilis (Bs) $\left(\mathrm{OD}_{600}=0.3\right)$ by soil application at two times (0 DAT, $30 \mathrm{DAT}), \mathrm{T}_{5}=$ Root dipping of seedlings for 30 min with $B s$ $\left(\mathrm{OD}_{600}=0.3\right), \mathrm{T}_{6}=\mathrm{T}_{4}+\mathrm{T}_{5}, \mathrm{~T}_{7}=$ Control (without Recharge or Bs. Artificial inoculation of ShB was done at 60 days after transplanting (DAT) in plants. Rhizoctonia solani was cultured on PDA medium and incubated at $26-28{ }^{\circ} \mathrm{C}$. After 7-10 days of incubation upto sclerotia formation, the inoculums were placed on the beneath of the rice plant into the sheath.

In spray method, bio-pesticides and others were applied by spraying at maximum tillering stage. The bio-pesticides along with chemical were sprayed at three days before inoculation and 4 days after inoculation @ 3\% w/v or v/v. Spray was done both as preventive and curative. Percent disease reduction was calculated over diseased control treatment. The bio-pesticides, bio-control agents along with chemical fungicide were sprayed at three days before inoculation and four days after inoculation @ 3\% (w/v or v/v) during maximum tillering stage of rice plant. Treatments were Recharge, Microtech1, Agroplus, Chitin, Chemical control (Nativo) and disease control (ShB inoculation but no spray).

Disease assessment. For assessing the percent relative lesion height (RLH) of sheath blight disease, data were taken from nine hills from each treatment following the Standard Evaluation System (IRRI, 2013). Plant height and lesion height were measured at 21 days after inoculation. The percent relative lesion height (RLH) was calculated following the formula:
Relative Lesion Height, RLH (\%) = (Lesion height/Total plant height) $\times 100$.

Experimental design and data analysis. The experiments were conducted by completely randomized design (CRD) with three replications. Whenever necessary, the data were distorted before statistical analysis following appropriate methods.

\section{RESULTS}

\section{Efficacy of bio-pesticides and bio-control agents in in-vitro against $R$. solani}

After 24 hours of dual contact, mycelial growth of $R$. solani was very low in Trichoderma harzianum (BT1), Recharge and chemical fungicide Nativo 75 WP. Similar and higher growth was observed in other bio-pesticides (Microtech 1, Agroplus, Chitin), Bacillus strain and control treatment (Figs. 1 and 3). In the dual contact, the radial growth of $R$. solani was obtained fully at 48 hours in control treatment. The radial growth of the fungus was significantly stopped on the PDA mediumcontaining BT1, Nativo $75 \mathrm{WP}$ and Recharge Bio-pesticide at 48 hours of incubation (Figs. 1 and 4).

Inhibition of mycelial growth over control. Inhibition of mycelial growth of $R$. solani over control at 48 hours after culturing was calculated. In case of fungal inhibition, highest percent inhibition of mycelial growth of $R$. solani was obtained in the PDA medium containing chemical fungicide Nativo (96\%) followed by Bio-pesticide Recharge (87\%) and Trichoderma strain BT1 (86\%) (Fig. 2). Other bio-pesticides (Microtech1, Agroplus and Chitin), Bacillus subtilis were not effective for inhibiting mycelia growth of $R$. solani as similar growth of ShB in this treatment was observed with control (no treatment) at 48 hours after dual culture (Figs. 2 and 4). This result suggests that Recharge and BT1 has the effective antifungal activity to $R$. solani, and they showed similar results as like chemical fungicide Nativo 75 WP. 


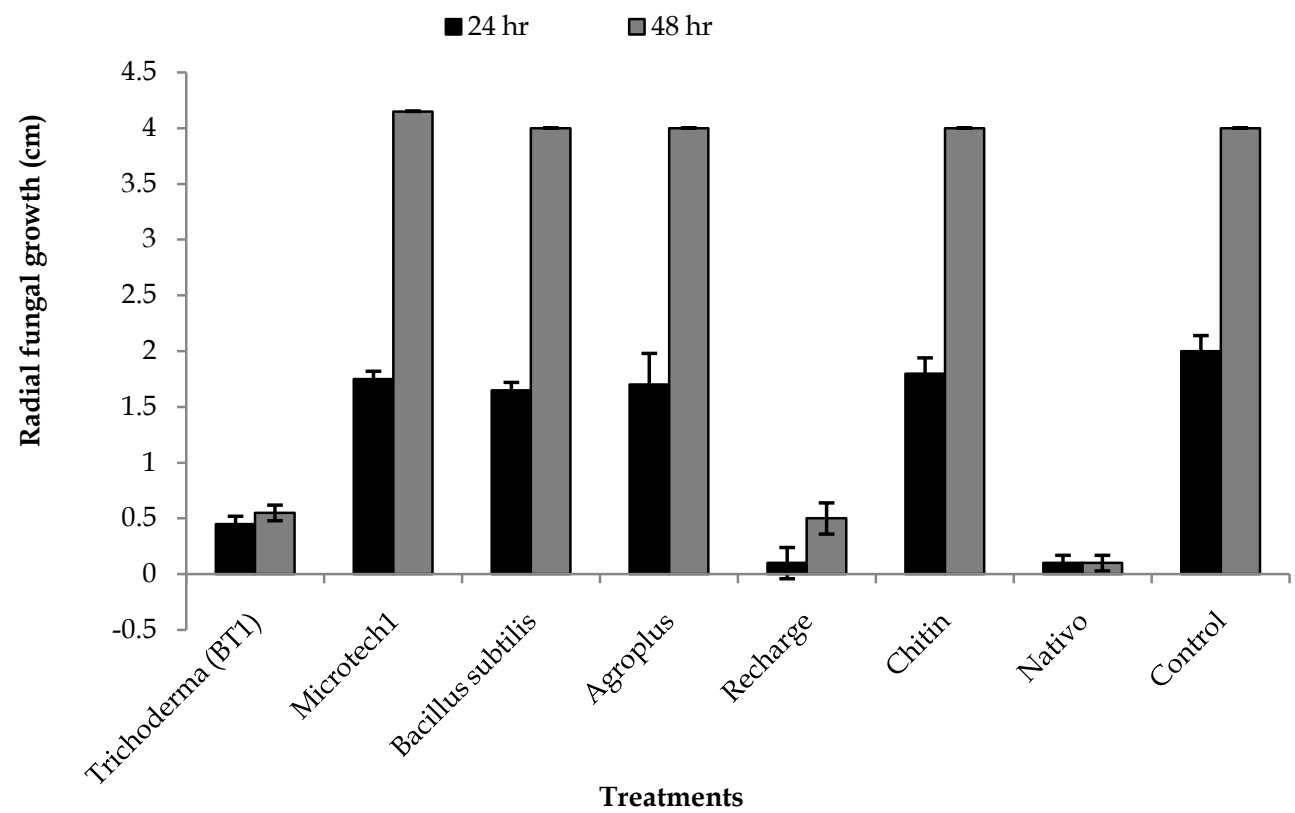

Fig. 1. Mycelial growth of Rhizoctonia solani on PDA medium in different bio-pesticides, bio-control agents and chemical fungicide at 24 and 48 hours of direct contact.

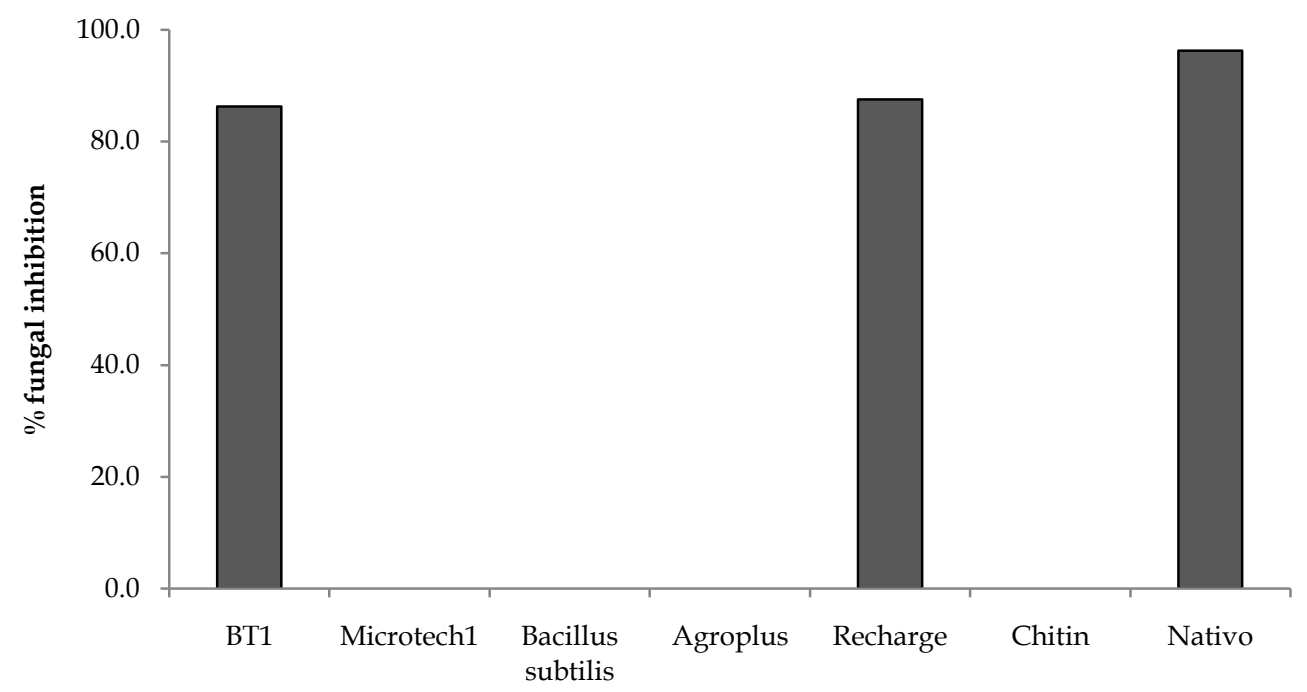

Treatments

Fig. 2. Inhibitory actions of bio-pesticides, bio-control agents and chemical fungicide over control treatment at 48 hours in in-vitro. 

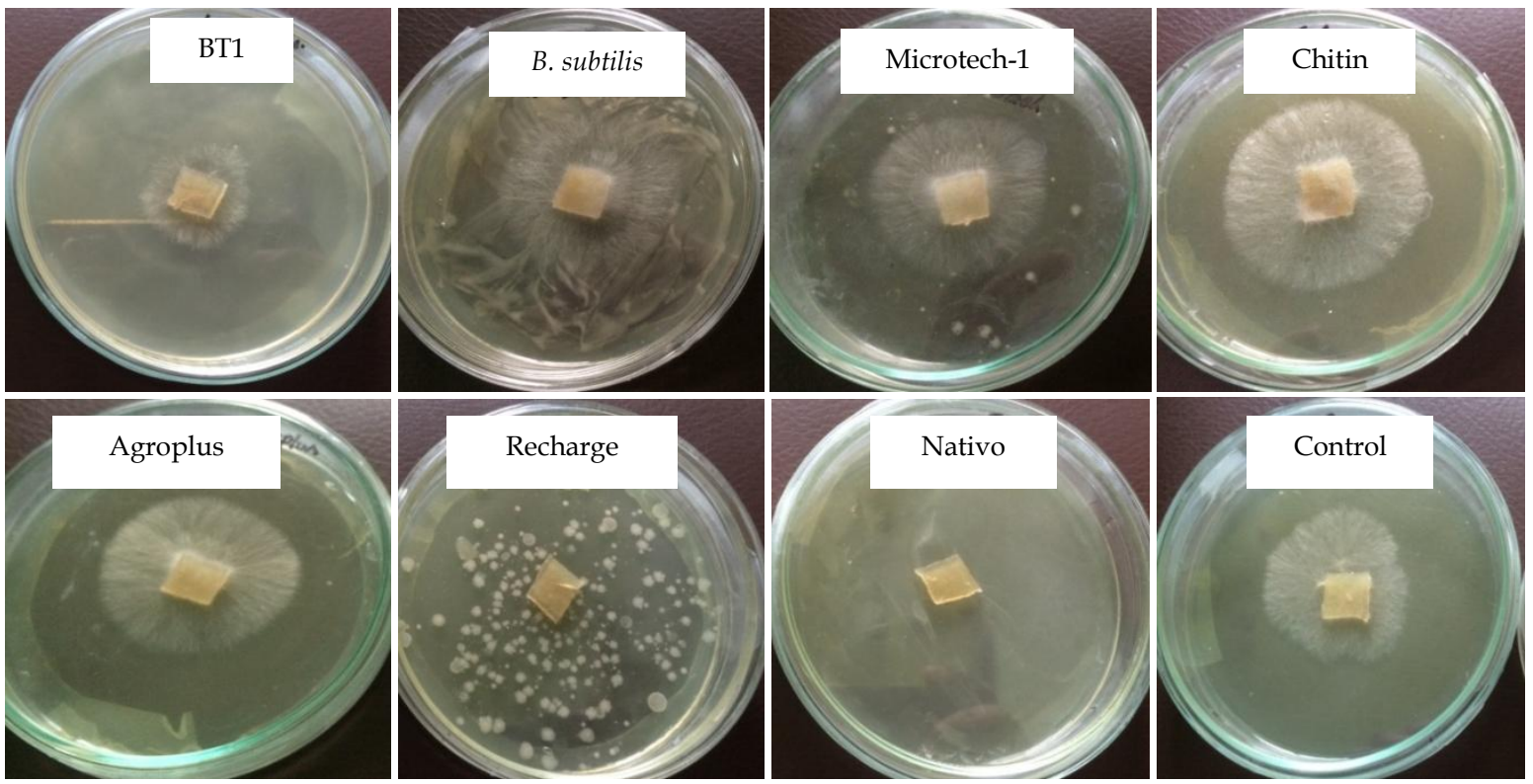

Fig. 3. Dual culture assay of Rhizoctonia solani with bio-pesticides, bio-control agents compared to chemical fungicide (Nativo) and control treatment on PDA medium at 24 hours after direct contact.
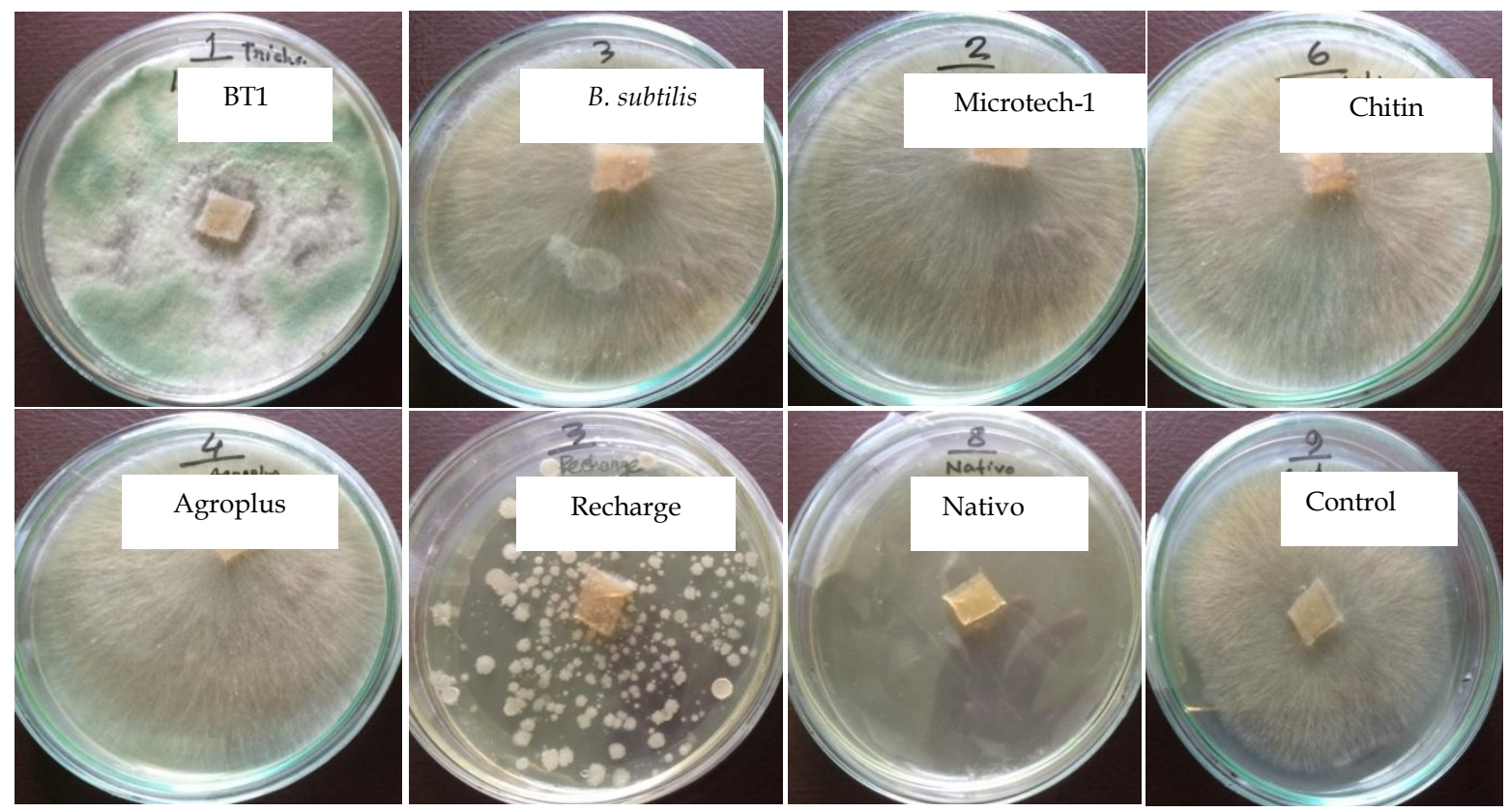

Fig. 4. Dual culture assay of Rhizoctonia solani with bio-pesticides, bio-control agents compared to chemical fungicide (Nativo) and control treatment on PDA medium at 48 hours after direct contact. 
Efficacy of bio-pesticides in net house condition against ShB disease of rice

Soil application and root dipping method. In this study, one bio-pesticide Recharge was found most effective in in-vitro experiment and that's why the effectiveness and appropriate application method of the biopesticide were investigated. Sheath blight disease was significantly decreased by the application of Recharge @ $0.3 \mathrm{~g} / \mathrm{m} 2$ in soil for two times during transplanting and 30 days after transplanting (DAT) compared to the other treatments (Fig. 5). Root dipping of the seedling with Recharge was also effective to some extent but not at acceptable level. Bacillus subtilis was not found effective on the $\mathrm{ShB}$ disease reduction. About $76 \%$ disease was reduced over control treatment by soil application of Recharge followed by root dipping (52\%) of the seedlings before transplanting (Fig. 6). This result indicates that efficacy of Recharge is more effective by soil application to control sheath blight disease of rice.

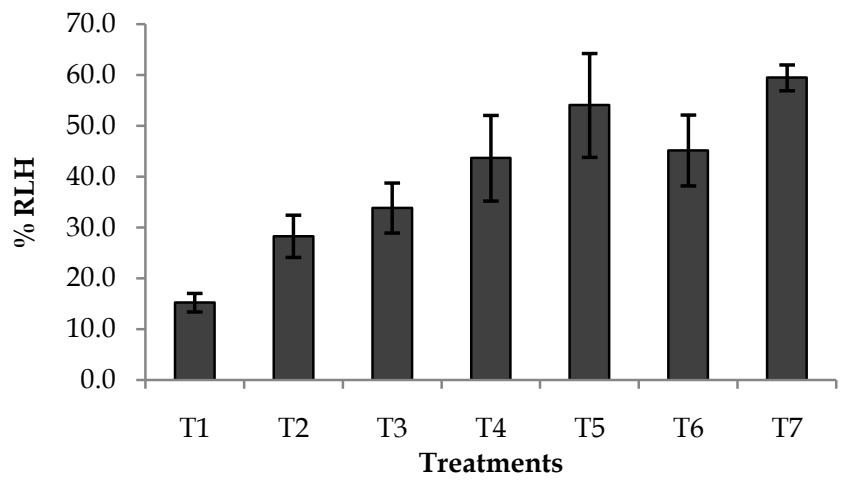

Fig. 5. Efficacy of bio-pesticides and bio-control agents against ShB disease of rice in net house condition by soil application method. \% Relative Lesion Height (RLH) of ShB disease showed. $\mathrm{T}_{1}=$ Use of Recharge $\left(0.3 \mathrm{~g} / \mathrm{m}^{2}\right.$ with $50 \mathrm{ml}$ water) by soil application two times (0 DAT, $30 \mathrm{DAT}), \mathrm{T}_{2}=$ Root dipping with Recharge $\left(0.3 \mathrm{~g} / \mathrm{m}^{2}\right.$ with $50 \mathrm{ml}$ water) of seedlings for $30 \mathrm{~min}, \mathrm{~T}_{3}=\mathrm{T}_{1}+\mathrm{T}_{2}, \mathrm{~T}_{4}=$ Bacillus subtilis $(B s)\left(\mathrm{OD}_{600}=0.3\right)$ by soil application two times $(0 \mathrm{DAT}, 30 \mathrm{DAT})$, $\mathrm{T}_{5}=$ Root dipping of seedlings for $30 \mathrm{~min}$ with $B$. subtilis, $\mathrm{T}_{6}=\mathrm{T}_{4}+\mathrm{T}_{5}, \mathrm{~T}_{7}=$ Control (without bio-pesticides).

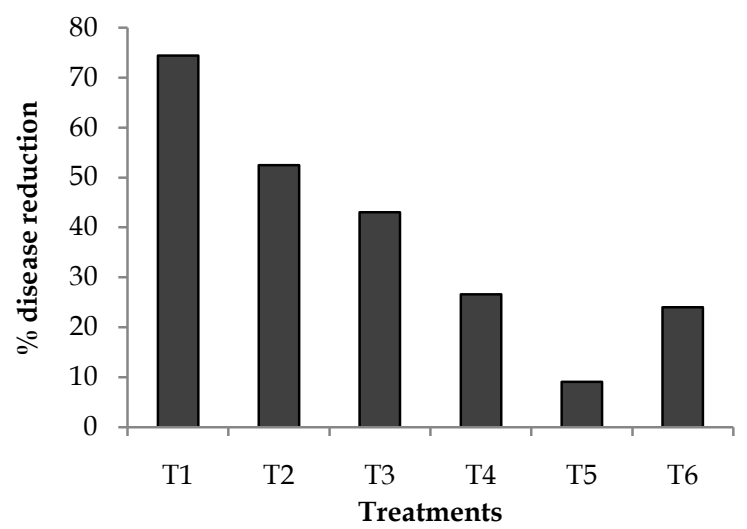

Fig. 6. Percent ShB disease reduction over control treatment in net house condition by application in soil. $\mathrm{T}_{1}=\mathrm{Use}_{\mathrm{p}}$ of Recharge $\left(0.3 \mathrm{~g} / \mathrm{m}^{2}\right.$ with $50 \mathrm{ml}$ water) by soil application two times $(0 \mathrm{DAT}, 30 \mathrm{DAT}), \mathrm{T}_{2}=$ Root dipping with Recharge $\left(0.3 \mathrm{~g} / \mathrm{m}^{2}\right.$ with $50 \mathrm{ml}$ water) of seedlings for $30 \mathrm{~min}, \mathrm{~T}_{3}=\mathrm{T}_{1}+\mathrm{T}_{2}, \mathrm{~T}_{4}=$ Use Bacillus subtilis $(B s)\left(\mathrm{OD}_{600}=0.3\right)$ by soil application two times (0 DAT, $30 \mathrm{DAT}), \mathrm{T}_{5}=$ Root dipping of seedlings for 30 min with $B s, \mathrm{~T}_{6}=\mathrm{T}_{4}+\mathrm{T}_{5}, \mathrm{~T}_{7}=$ Control (without Recharge or Bs). 
Spray method. After 21 days of inoculation, sheath blight disease was significantly reduced by spraying of Trichoderma harzianum (BT1) and recharge (Fig. 7). Disease was mostly controlled by spraying the chemical fungicide Nativo 75 WP. Disease reduction of $89 \%$ was obtained by spraying Trichoderma harzianum (BT1) and $94 \%$ by chemical fungicide Nativo 75 WP and $71 \%$ disease was inhibited by Recharge over diseased control treatment (Fig. 8). Though the chemical fungicide performed the best but besides the chemicals, Recharge and Trichoderma harzianum (BT1) can be the environmentally friendly alternative option of chemicals for controlling ShB disease of rice. Further field experiments with Recharge and formulations of Trichoderma harzianum (BT1) are needed in different locations to clarify the present study.

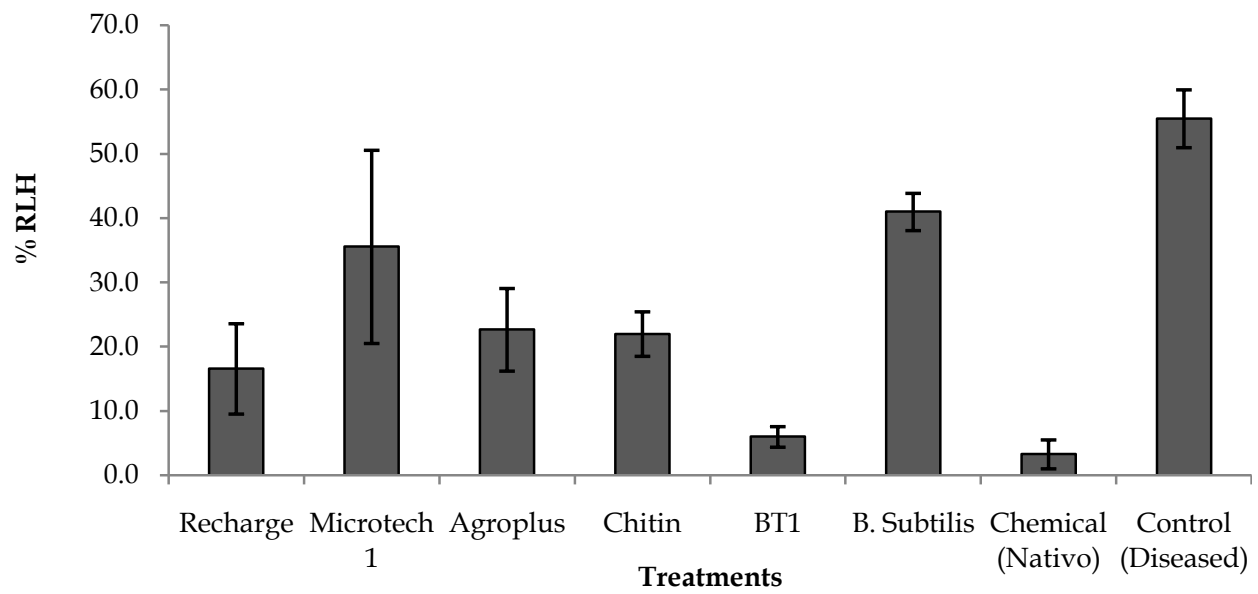

Fig. 7. Efficacy of bio-pesticides and bio-control agents against ShB disease of rice in net house condition by spray method. \% Relative Lesion Height (RLH) of ShB disease data were collected during 21 days after inoculation. The bio-pesticides, bio-control agents along with chemical were sprayed at three days before inoculation and four days after inoculation @ 3\%w/vorv/v.

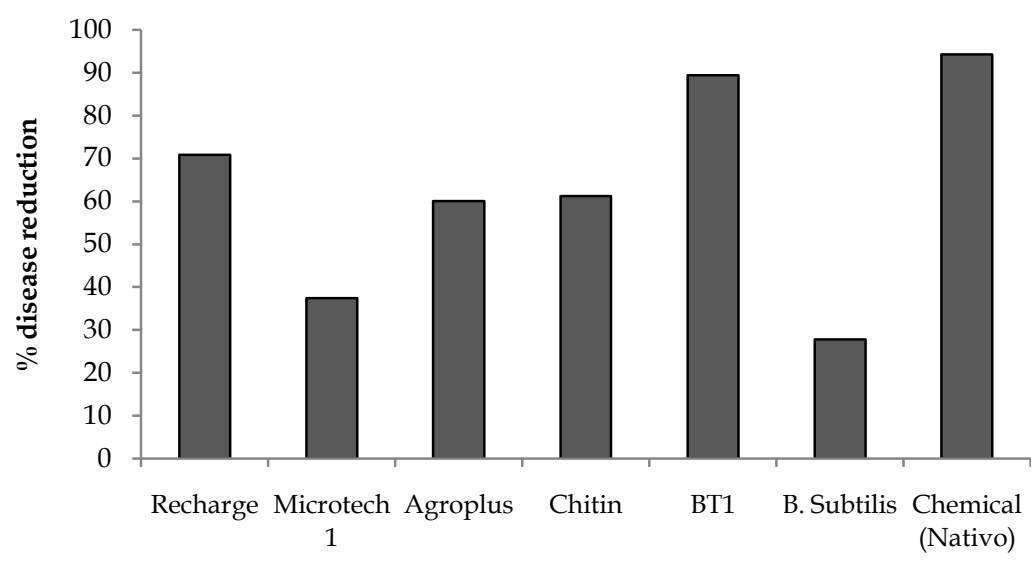

Treatments

Fig. 8. Percent ShB disease reduction over diseased control treatment in net house condition by spray method. Data of $\%$ Relative Lesion Height (RLH) of ShB disease were used for calculating disease reduction over diseased control. 


\section{DISCUSSION}

Bio-pesticides are potential alternatives to chemical pesticides. Microbial bio-pesticides are living natural enemy organisms and/or their products including plant and microbial products and/or their byproducts and they could reduce pathogen populations. In the present decade, bio-pesticides are widely acceptable and demanded for sustainable agriculture and for production of safe foods. It was significantly considered that, biopesticides are eco-friendly, target-specific, easily biodegradable and safer alternatives. Economically, chemical pesticides are very expensive in comparison to bio-pesticides. Many scientists in the world developed and experimentally validated different biopesticides and bio-control agents for controlling different diseases including rice diseases (Kazempour, 2004; Chowdhury et al., 2013; Sindhu et al., 2016; Naeimi et al., 2019; Raj et al., 2019).

The biological control of plant diseases is a promising alternative approach to maintaining plant health and promoting crop yield. Several bacterial isolates including $B$. subtilis from soil are effective against the fungal pathogen R. solani (Kang et al., 2015; Raj et al., 2019). One UK's Bio-pesticide (Recharge), three Bangladeshi company's bio-pesticides (Microtech 1, Agroplus, Chitin), two biocontrol agents (Trichoderma harzianum and Bacillus subtilis) were tested against one of the major rice diseases sheath blight caused by Rhizoctonia solani in in vitro and net house conditions and the results were compared with one chemical control and another is control (no treatments, only sterilized water). Bio-pesticide Recharge was found effective antagonist to $R$. solani in in vitro and in net house condition. The findings of the present study also supporting by the findings of Hossain et al. (2001) and Bashar et al. (2010), who showed bacterial isolates exhibited comparatively higher growth inhibition of $R$. solani. Bashar et al. (2010) reported that ShB disease development reduced tremendously when antagonistic bacteria treated sclerotia were inoculated. The tested isolates of antagonistic bacteria reduced sheath blight disease development upto $35 \%$ over to control.

Elkahoui et al. (2012) reported that two bacterial strains, Bacillus subtilis and Bacillus cereus, showed a clear antagonism against $R$. solani on potato dextrose agar (PDA) medium. Elkahoui et al. (2011) also found some bacterial isolates collected from Marine Bio-Films for antifungal activity against $R$. solani. The tested strain of Bacillus subtilis didn't show any inhibitory reaction on $R$. solani in the same condition. It might be the differences of the species of Bacillus strains. Many researchers reported different bio-control agents effective to control sheath blight causing pathogen $R$. solani (Harman et al., 2004; Jacobsen et al., 2004; Kloepper et al., 2004; Kumar et al., 2009a \& 2009b; Peng et al., 2014; Mishra et al., 2015; Shrestha et al., 2016).

Our results also showed that one strain of Trichoderma harzianum (BT1) can reduce more than $70 \%$ sheath blight disease and similar results was found with the report of Naeimi et al. (2019). Sharma et al. (2012) also reported that Trichoderma-based enzymes (chitin and glucans) are known to show pest resistant activity. Studies concerning commercialization and field applications of integrated stable bio-formulations of Trichoderma harzianum (BT1) as an effective bio-control strategy would be needed in future. Recharge bio-pesticide was found comparatively better than the other biopesticides tested. The recommended application methods of Recharge Biopesticide are soil application and spray method. In order to fully exploit Recharge potential, further studies on field experiments are required to establish it as an effective Biopesticide for controlling sheath blight disease along with other major rice diseases. 


\section{CONCLUSION}

From this study, Trichoderma harzianum (BT1) could be suggested as Bio-pesticide with suitable formulation followed by field trial. Bio-pesticide Recharge could also be used as Bio-pesticide for controlling sheath blight disease of rice after some field trial by using soil application as well as spray method. Biopesticides can be a satisfactory substitute to the chemical pesticide when used as part of an overall integrated disease management plan. Advances in Bio-pesticide technology like use of beneficial microbes, nanopesticide, encapsulation, Recombinant DNA technology make Bio-pesticide more effective, selective or specific and cause less environmental pollution and less toxic to mammals as compared to conventional pesticides.

\section{AUTHORS' CONTRIBUTION}

MMR, MAIK and MAL generated idea; MAH, $\mathrm{NH}, \mathrm{MMR}$ and MAL coordinated the experiment/research/project; MMR, MAIK and MAL developed methodology; MAH and NH provided scientific insights; MMR, MRB and HAD gathered data and carried out analysis and synthesis; MMR did the writings for all versions of the manuscript; MAL and MAIK performed critical review and editing; All authors read and approved the final manuscript.

\section{ACKNOWLEDGMENT}

Authors are very much grateful to Russel IPM, UK and authority of Bangladesh Rice Research Institute (BRRI) Gazipur for providing financial and research support, respectively.

\section{DECLARATION OF INTERESTS}

Every author accepts and consents to the publishing of the manuscript. The authors declare having no conflicting interests.

\section{REFERENCES}

Arora, N K, E Khare and D K Maheshwari. 2010. Plant Growth Promoting Rhizobacteria: Constraints in Bioformulation, Commercialization, and Future Strategies. In: Maheshwari D. (eds) Plant Growth and Health Promoting Bacteria. Microbiology Monographs, vol 18. Springer, Berlin, Heidelberg. DOI: https://doi.org/10.1007/978-3-642-13612-2_5

Arora, N K, S Tewari, S Singh, N Lal and D K Maheshwari. 2012. PGPR for Protection of Plant Health Under Saline Conditions. In: Maheshwari D. (eds) Bacteria in Agrobiology: Stress Management. Springer, Berlin, Heidelberg. https://doi.org/10.1007/978-3642-23465-1_12

BRRI (Bangladesh Rice Research Institute). 2018. Survey and monitoring of rice diseases in different agroecological zones in Bangladesh. Annual Research Report. Plant Pathology Division.

Bashar, M A, M A Hossain, M M Rahman, M N Uddin and M N Begum. 2010. Biological Control of Sheath Blight Disease of Rice by using Antagonistic Bacteria. Bangladesh Journal of Scientific and Industrial Research. 45 (3): 225-232. DOI: https://doi.org/ 10.3329/bjsir.v45i3.6529

Brent, K J and D W Hollomon. 1998. Fungicide resistance in crop pathogens: How can it be managed? Fungicide Resistance Action Committee 2007.

Chowdhury, S P, K Dietel, M Randler, M Schmid, H Junge, R Borriss, A Hartmann and R Grosch. 2013. Effects of Bacillus amyloliquefaciens FZB42 on lettuce growth and health under pathogen pressure and its impact on the rhizosphere bacterial community. PLoS ONE, 8:e68818. DOI: 10.1371 /journal.pone.0068818

Dubey, R C, H Kumar and P R Pandey. 2009. Fungitoxic Effect of Neem Extracts on Growth and Sclerotial Survival of Macrophomina phaseolina in vitro. Journal of American Science. 5: 17-24.

Elkahoui, S, N Djébali, O Tabbene, A Hadjbrahim, B Mnasri, R Mhamdi, M Shaaban and F Limam. 2012. Evaluation of antifungal activity from Bacillus strains against Rhizoctonia solani. African Journal of Biotechnology. 11(18): $\quad$ 4196-4201. DOI: $10.5897 / \mathrm{AJB11} .3354$

Elkahoui, S, N Djébali, O Tabbene, A Hadjbrahim, B Mnasri, R Mhamdi and F Limam. 2011. Screening of Bacterial Isolates Collected from Marine Bio-Films for Antifungal Activity against Rhizoctonia solani. Dynamic Biochemistry, Process Biotechnology and Moecular Biology. 5(2): 1-4.

Gerhardson, B. 2002. Biological substitutes for pesticides. Trends Biotechnology. 20: 338-343. DOI: 10.1016/ s0167-7799(02)02021-8 
Groth, D E. 2005. Azoxystrobin rate and timing effects on rice sheath blight incidence and severity and rice grain and milling yields. Plant Disease. 89:1171-1174. DOI: 10.1094/PD-89-1171

Harman, G E, C R Howell, A Viterbo and I Chet. 2004. Trichoderma spp.: opportunistic avirulent plant symbionts. Nature Reviews. 2: 43-56. DOI: $10.1038 /$ nrmicro797

Hossain, M. and M A T Mia. 2001. Management of sheath blight disease of rice under farmer's field condition. Bangladesh Journal of Plant Pathology. 17(1/2): 13-16.

IRRI (International Rice Research Institute). 2013. Standard Evaluation System for Rice. International Rice Research Institute, Los Banos, Philippines.

Islam, M R, N E T Islam, P S Juthy, M M Haque and M M Rahman. 2019. Identification of plant growth promoting antagonistic bacteria against Xanthomonas oryzae pv. oryzae in Bangladesh. Fundamental and Applied Agriculture. 4(4): 1068-1080. DOI: $10.5455 /$ faa. 67224

Jacobsen, B J, N K Zidack and B J Larson. 2004. The role of Bacillus-based biological control agents in integrated pest management systems: plant diseases. Phytopathology. $\quad 94(11): \quad$ 1272-1275. DOI: https://doi.org/10.1094/PHYTO.2004.94.11.1272

Kang, S M, R Radhakrishnan and I J Lee. 2015. Bacillus amyloliquefaciens subsp. plantarum GR53, a potent bio-control agent resists Rhizoctonia disease on Chinese cabbage through hormonal and antioxidants regulation. World Journal of Microbiolgy and Biotechnology. 31: 1517-1527. DOI: 10.1007/s11274-015-1896-0.

Kazempour, MN. (2004) Biological control of Rhizoctonia solani, the causal agent of rice sheath blight by antagonistic bacteria in greenhouse and field conditions. Plant Pathology Journal. 3: 88-96.

Kloepper, J W, C M Ryu and S Zhang. 2004. Induced systemic resistance and promotion of plant growth by Bacillus spp. Phytopathology. 94(11): 1259-66. DOI: 10.1094/PHYTO.2004.94.11.1259

Kumar, K V K, M Reddy, J W Kloepper, K K Lawrence, D E Groth and M E Miller. 2009a. Sheath blight disease of rice (Oryza sativa L.) - An overview. Bioscience Biotechnology Rersarch Asia. 6: 465-480. DOI: http:/ / www.biotech-asia.org/?p=8629

Kumar, K V K, M Reddy, J W Kloepper, K K Lawrence, D E Groth, M E Miller and D Binghai. 2009b. In-vitro efficacy of various rhizobacterial isolates against Rhizoctonia solani, the causal agent of rice sheath blight disease. Plant growth promotion by rhizobacteria for sustainable agriculture. India: Scientific Publishers.

Latif, M A, M A Badsha, M I Tajul, M S Kabir, M Y Rafii and MAT Mia. 2011. Identification of genotypes resistant to blast, bacterial leaf blight, sheath blight and tungro and efficacy of seed treating fungicides against blast disease of rice. Scientific Research and Essays. 6 : 2804-2811. https://doi.org/10.5897/SRE11.315

Manoharachary, C, I K Kunwar, and A B Rajithasri. 2014. Advances in applied mycology and fungal biotechnology. Kavaka. 43: 79-92.

Miah, S A, A K M Shahjahan, M A Hossain and N R Sharma. 1985. Survey of rice diseases in Bangladesh. Tropical Pest Management. 31(3): 208-213. https://doi.org/10.1080/09670878509370984

Mishra, J, S Tewari, S Singh, and NK Arora. 2015. Biopesticides: Where We Stand?. In Plant Microbes Symbiosis: Applied Facets. 37-75. DOI: https://doi.org/10.1007/978-81-322-2068-8_2

Misk, A and C Franco. 2011. Bio-control of chickpea root rot using endophytic actinobacteria. Bio-control . 56: 811-822. DOI: $10.1007 /$ s10526-011-9352-Z

Naeimi, S, V Khosravi, M Z Nouri, H Hoda, C Vágvölgyi and L Kredics. 2019. Biological control of rice sheath blight disease with formulation of indigenous Trichoderma strains under paddy field conditions. Acta Biologica Szegediensis. 63(3): 37-43. DOI: 10.14232/abs.2019.1.37-43

Ou, SH. 1985. Rice Diseases, Second Edition, CHI, Kew, Surrey, The England. 38.

Peng, D, S Li, J Wang, C Chen and M Zhou. 2014. Integrated biological and chemical control of rice sheath blight by Bacillus subtilis NJ-18 and jinggangmycin. Pest Management Science. 70(2): 25863. DOI: $10.1002 /$ ps.3551

Raj, T S, A Muthukumar, P Renganathan, R S R Kumar and H A Suji. 2019. Biological control of sheath blight of rice caused by Rhizoctonia solani Kuhn using marine associated Bacillus subtilis. International Archive of Applied Sciences and Technology. 10 (4): 148153. DOI: 10.15515/iaast.0976-4828.10.4.148153

Satish, S, D C Mohana, M P Ranhavendra and K A Raveesha. 2007. Antifungal activity of some plant extracts against important seed borne pathogens of Aspergillus spp. Journal of Agricultural Technology. 3: 109-119.

Savary, S, P S Teng, L Willocquet, F W Nutter. 2006. Quantification and modeling of crop losses: A review of purposes. Annual Review of Phytopathology. 44: 89-112. 
Shahjahan, A K M and T W Mew. 1986. Sheath spot of rice in the Philippines. International Rice Research. 11(3): 17.

Sharma, R, J Arunab and C D Ramesh. 2012. A brief review on mechanism of Trichoderma fungus use as biological control agent. International Journal of Innovations in Bio-Sciences. 2 (4): 200-210.

Shrestha, B K, H S Karki, D E Groth, N Jungkhun and J H Ham. 2016. Biological Control Activities of RiceAssociated Bacillus sp. Strains against Sheath Blight and Bacterial Panicle Blight of Rice. PLOS ONE, 11(1): e0146764. DOI:10.1371/journal.pone.0146764

Sindhu, SS, A Sehrawat, R Sharma and A Dahiya. 2016. Bio-pesticides: Use of Rhizosphere Bacteria for Biological Control of Plant Pathogens. Defence Life Science Journal. 1 (2): 135-148. DOI: 10.14429/ dlsj.1.10747

Wang X, C Wang, Q Li, J Zhang, C Ji, J Sui, Z Liu, X Song, $X$ Liu. 2018. Isolation and characterization of antagonistic bacteria with the potential for biocontrol of soil- borne wheat diseases. Journal of
Applied Microbiology. $125 \quad$ (6): $1868-1880$.

DOI: https://doi.org/10.1101/325647

Yang, L, J Xie, D Jiang, Y Fu, G Li and F Lin. 2007. Antifungal substances produced by Penicillium oxalicum strain PY-1-potential antibiotics against plant pathogenic fungi. World Journal of Microbiology and Biotechnology. 24: 909-915. DOI: 10.1007/s11274007-9626-x

Zheng, A, R Lin, D Zhang, P Qin, L Xu, P Ai, L Ding, Y Wang, Y Chen, Y Liu, Z Sun, H Feng, X Liang, R Fu, C Tang, Q Li, J Zhang, Z Xie, Q Deng and S Li. 2013. The evolution and pathogenic mechanisms of the rice sheath blight pathogen. Nature Communications. 4(1): 1424. https://doi.org/ $10.1038 /$ ncomms2427

Zhong, T W, Z Wei, O Z Qi, L C Wen, Z GuanJun, K W Zhi and Y Li. 2007. Analysis of temporal development and yield losses due to sheath blight of rice (Rhizoctonia solani AG-1A). Agricultural Science in China. 6: 1074-1081. DOI: https://doi.org/10.1016/ S1671-2927 (07) 60149-7 